\title{
The Prevalence of Negative Teacher-Related Factors in a Ghanaian Municipality's Basic Schools
}

\author{
Ernest Osei \\ Department of Educational Administration and Management \\ University of Education, Winneba. \\ Dominic Kwaku Danso Mensah \\ Department of Educational Administration and Management \\ University of Education, Winneba.
}

\begin{abstract}
Our paper explored teacher- related factors responsible for low academic performance of junior high school pupils in the Effutu municipality of Ghana. We adopted the descriptive survey research design and educational productivity theory (theoretical framework) for this study. Questionnaires were used to gather data from three hundred participants. Using purposive sampling technique, the researchers selected 300 public basic school teachers as participants for the study. Using simple percentages and frequencies we established that several teacher- related factors contributed toward pupils' low academic performance in the municipality. These include a lack of teacher job satisfaction leading to poor work habit, teachers failure to use teaching and learning materials, inability to complete the syllabi, a lack of opportunities for continuous professional development, poor preparation of lesson note, teacher lateness and absenteeism and less remedial teaching to improve pupils academic performance. We therefore recommend effective supervision of teachers' instructional activities by circuit supervisors and head teachers. In addition, the Ghana Education Service should ensure adequate provision of teaching and learning materials and a possible review of teacher remuneration, incentives and allowances for improved teacher job satisfaction. More so, there should be regular organization of in -service training for teachers to sensitize them on various opportunities available for continuous professional development in order to improve their knowledge and skills based and its likely increase in educational outcomes.
\end{abstract}

\section{INTRODUCTION}

The low academic performance of some pupils at the basic education level have been a source of concern to parents, teachers, pupils, educational administrators, governments and research interest to researchers. This is so because of the great importance that education has on the national development of the country. Education is an investment as well as an instrument that can be used to achieve a more rapid economic, social, political, technological, scientific, and cultural development in the country. Education promotes the development of the right citizenship as a basis for effective participation and contribution to the life of the society. It also assists in developing the individual's ability to adapt to changing environments and inculcating character and moral training and the development of sound mind (Aremu \& Oluwole, 2000). Ghana as a nation recognizes this crucial role which education plays in human and with socioeconomic development. The development of the education sector has therefore been a longstanding objective of the government of Ghana right from her pre-independence days and several efforts made at revamping the ailing basic education in the country (Arthur Dickson, 2011). 
It is important for a nation to realize its potential through well-educated labor force for development. It therefore becomes worrying when a nation records low students' achievement scores in standardized examination. However, an overarching question remains; how do we describe pupil's academic performance as poor? The term poor academic performance has no one acceptable definition based on the broad nature of it. According to Okoye (1982), poor academic performance in individuals or candidates in a learning situation refer to one who fails to attain a set standard performance in a given evaluation exercise such as test, examination or series of continuous assessments. This means that the standard could be based on a number of stipulated subjects and other school activities. A candidate who scores less or below a given standard can be described as performing poor academically.

Invariably, the role of basic education is to lay the foundation for further education and if a good foundation is laid at this level, children are likely to perform well on several life kills at subsequent levels. However, different people at different times have passed the blame of poor performance in secondary school to students because of their low retention, parental factors, association with wrong peers, low achievement, low achievement motivation, and the likes (; Aremu, 2000; Aremu \& Oluwole 2001; Aremu \&Sokan, 2003). Similarly, stakeholders in education in the Ewutu Municipality might not be different when engaged in the blame game on why their students failed.

Pupil's performance is defined as the ability of pupils to do something (Oxford Advanced Learners Dictionary, 1994). Performance also refers to the pupils' level of achievements / attainment of knowledge and skills compared to others. Academic performance refers to the quality and quantity of knowledge, skills techniques, and positive attitudes, behavior and philosophy that learners achieve or acquire (Ferguson, 1990). This ability is evaluated by the marks and grades that the pupils attain in a test or examination, which is done at the end of a topic, school term, and year or education cycle.

According to Etsey (2005), the teacher factors are those that could hinder or promote academic performance of pupils in schools. Archer (1999) and Armentano (2003) as cited in Nyarko (2010) also argued that teachers are the most important influence on student progress, even more important than socioeconomic status and school location. The teacher factors found to contribute to the low academic performance include; teacher commitment, teachers' frequency of absenteeism, teachers' motivation, and teachers' work load (Etsey, 2005). Furthermore, Darling-Hammond (2000) concludes that measures of teacher preparation and certification are by far the strongest correlates of student achievement in reading and mathematics. Agyeman (1993) reported that a teacher who does not have both the academic and the professional teacher qualification would undoubtedly have a negative influence on the teaching and learning of his/her subject. The means or strategies employed by teachers in an attempt to impact knowledge to the learner is referred to as methodology and these have influence on students' academic performance. Osokoye (1996) sees teaching method as the strategy or plan that outlines the approach that teachers intend to take in order to achieve the desirable objectives. It involves the way teachers organize and use techniques of subject matter, teaching tools, and teaching materials to meet teaching objectives. To enhance effective teaching and learning, teachers must ensure that pupils are able to carry out the behavioral or instructional objectives of lessons taught.

\section{Statement of the Problem}

Empirically, the performance of public junior high school pupils of the Effutu municipality in the Basic Education Certificate Examination (BECE) from 2013 to 2016 indicated that the academic achievement of the pupils was declining (Table 1). 
Table 1: Basic Education Certificate Examination (BECE) Results (2013-2016)

\begin{tabular}{lcccc}
\hline & $\mathbf{2 0 1 3}$ & $\mathbf{2 0 1 4}$ & $\mathbf{2 0 1 5}$ & $\mathbf{2 0 1 6}$ \\
\hline Total number of candidate & 926 & 976 & 891 & 934 \\
No. of candidate who passed & 264 & 283 & 266 & 291 \\
Percentage passed & $28.5 \%$ & $28.9 \%$ & $29.85 \%$ & $31.25 \%$ \\
No. of candidate who failed & 662 & 693 & 625 & 643 \\
Percentage failed & $71.5 \%$ & $71.1 \%$ & $70.15 \%$ & $68.75 \%$ \\
\hline
\end{tabular}

Source: Statistics Office, Effutu Education Directorate. (2017)

A study of the above BECE results of the pupil from 2013 to 2016 reveals that, in 2013 , nine hundred and twenty six (926) junior high school (JHS) pupils were registered for the BECE examinations, out of which only $264(28.5 \%)$ passed. $662(71.5 \%)$ of the pupils failed.(Effutu Municipal Ghana Education Service, 2014). In 2014, a similar trend was witnessed with nine hundred and seventy six (976) junior high school pupils who wrote the BECE examinations, only 284 (28.9\%) passed with 693 (71.1\%) failing (Effutu Municipal, Ghana Education Service, 2015). Also another abysmal performance was recorded in 2015 where 891 junior high school (JHS) pupils participated in the BECE examinations, only 266 (29.85\%) passed and 625 $(70.15 \%)$ of the candidate failed.

In 2016934 junior high school pupils were registered for the BECE examinations, out of which only 291 (31.25\%) passed. Similarly, 643 (68.75\%) of the pupils failed (Effutu Municipal Ghana Education Service, 2017). The above analysis reveals that in the past four years, pupils' performance in the BECE has been deteriorating. While few pupils succeeded in their examination, the majority of the pupils performed poorly. It is worth mentioning that a variety of factors might be responsible for low academic performance among pupils. These factors may include student-related factors, teacher-related factors, school-related factors, parent-related factors and medical and psychological -related factors etc. Adane (2010) also mentioned school, teacher, and pupils related. Therefore, the researchers of the current study set out to ascertain which teacher-related factors can contribute to the declining academic performance of public junior high schools pupils in the Effutu municipality of Ghana.

\section{Significance of the study}

The study would be of significance to various educational stakeholders. The findings of this study would enable teachers to acquire knowledge on the various characteristics teachers possess and how they influence pupils' academic performance. The study also would assist educational policy makers to recognize important personal qualities and activities, which require assessment in order to support teachers in improving the academic performance of their students. Furthermore, the study would add to the extant literature on the subject of teacher characteristics and its influence on the academic performance of students in schools and thus serve as reference point to future research works.

\section{THEORETICAL FRAMEWORK}

Walberg's (1981) theory of educational productivity was empirically tested as one of very few theories of academic achievement. Walberg's theory of academic achievement posits that psychological characteristics of individual students and their immediate psychological environments influence educational outcomes (cognitive, behavioral, and attitudinal) (Reynolds \& Walberg, 1992). Further, Walberg's research identified nine key variables that influence educational outcomes as: student ability/prior achievement, motivation, age, /developmental level, quantity of instruction, quality of instruction, classroom climate, home environment, peer group, and exposure to mass media outside of school. Theory of Educational Productivity by Walberg (1981) also determined three groups of nine factors based on 
affective, cognitive and behavioral skills for optimization of learning that affect the quality of academic performance: Aptitude (ability, development and motivation); instruction (amount and quality); environment (home, classroom, peers and television). Walberg states that three groups: student aptitude, instruction, and environment influence educational outcomes.

Student aptitudes include:

1) ability or prior achievement, as measured by the usual standardized tests,

2) development, as indexed by chronological age or stage of maturation, and

3) motivation, or self-concept, as indicated by personality tests or the student's willingness to persevere intensively on learning tasks.

Instruction includes:

4) the amount of time students engage in learning and

5) the quality of the instructional experience, including psychological and curricular aspects.

Four environmental factors also consistently affect learning: the educationally stimulating, psychological climates of

6) the home,

7) the classroom and social group,

8) the peer group outside the school, and

9) use of out-of-school time (specifically leisure-time television viewing).

\section{METHODOLOGY}

This segment describes the methods used during data gathering, analysis, and interpretation of results. The research design, sampling, instrumentation, and data collection procedures, and analysis are described.

\section{Research Design}

The design for the study was the descriptive survey design. According to Weirsma (1980), Surveys are useful for gathering facts in order to establish important and useful information for the educational enterprise. Survey methods collect data through questionnaires or/ and interviews (Orodho, 2005). According to Gay (1992), descriptive survey design studies can provide information about the naturally occurring behavior, attitudes, or other characteristics of a particular group. The researchers' intention for the use of this type of design was because surveys are frequently used to collect information on attitudes and behaviors of phenomena (Polland, 2005) and since the topic being studied is about the behaviors of a group of people, the researchers considered it as a more appropriate research design for the current study.

\section{Sample Size and Sampling Technique}

The researchers used purposive sampling to select a total number of 300 public basic school teachers in the Effutu Municipality. Creswell (2009) stated that, in purposive sampling, researchers intentionally select individuals and sites to learn or understand a phenomenon. Cohen, Manion, and Morrison (2003) cited in Avoke (2005) also assert that purposive sampling enables researchers to handpick the cases to be included in the sample based on their judgment and typicality. In this way, the researcher builds up a sample that is satisfactory to specific needs.

\section{Research Instrument}

The research instrument used for this study was questionnaire to measure teacher-related factors responsible for the declining academic performance of pupils in the Effutu municipality. 
Structured questionnaire was used because the entire population was highly literate or well educated.

\section{Data Collection Procedure}

The researchers visited the schools under study, at the various schools; the researchers introduced themselves to the teachers and briefed them about the purpose of their visit and study. The questionnaires were administered to the teachers and returned back to the researcher soon after completion. In order to ensure the validity and reliability of the research instrument, the test and re-test method was used to determine the reliability coefficient of the questionnaire instrument at an interval of one month between the first and second. This produced reliability coefficient $(\mathrm{r}$ ) of 0.813 indicating that the instrument was relatively reliable.

\section{Research question 1}

\section{DATA PRESENTATION AND ANALYSIS}

\section{What are the teacher-related factors responsible for the declining academic performance} of pupils in the Effutu municipality of Ghana?

The teacher-related factors considered were teacher job satisfaction, availability, and adequacy of teachers, availability, and adequacy of teaching and learning materials teacher-pupil teaching and learning interaction, frequency of lateness and absenteeism, lesson note preparation and vetting, and completion of syllabi.

Table 2: Teacher Job Satisfaction, Availability, and Adequacy of Teachers

\begin{tabular}{|c|c|c|c|c|c|c|c|c|}
\hline Statements & $\begin{array}{l}\text { SD } \\
\text { Fre }\end{array}$ & q. $\%$ & $\begin{array}{l}\text { D } \\
\text { Free }\end{array}$ & $\%$ & $\begin{array}{l}\text { A } \\
\text { Freo }\end{array}$ & q. $\%$ & $\begin{array}{l}\text { SA } \\
\text { Fre }\end{array}$ & q. $\%$ \\
\hline It is my choice to be a teacher. & 90 & 30 & 102 & 34 & 68 & 22.7 & 40 & 13.3 \\
\hline $\begin{array}{l}\text { Generally, teachers have good work habit or } \\
\text { attitude towards the teaching profession. }\end{array}$ & 68 & 22.7 & 148 & 49.3 & 48 & 16 & 36 & 12 \\
\hline $\begin{array}{l}\text { The working conditions attached to the teaching } \\
\text { profession are satisfactory enough to meet the } \\
\text { economic conditions of the country. }\end{array}$ & 90 & 30 & 114 & 38 & 66 & 22 & 30 & 10 \\
\hline $\begin{array}{l}\text { There are opportunities for continuous } \\
\text { professional development in the teaching service. }\end{array}$ & 68 & 22.7 & 118 & 39.3 & 88 & 29.3 & 26 & 8.7 \\
\hline $\begin{array}{l}\text { There are available and adequate professional } \\
\text { teachers for all subject }\end{array}$ & 38 & 12.7 & 28 & 9.3 & 190 & 60 & 54 & 18 \\
\hline
\end{tabular}

\section{Source: Field work data (2017).}

Key: $S D=$ Strongly Disagree; $D=$ Disagree; $A=$ agree; $S A=$ Strongly Agree

Job satisfaction includes all the characteristics if the job itself and work environment which workers find rewarding, fulfilling and satisfying (Churchill, Fill \& Walker, 1974). An individual's attitude towards his/her job has considerable influence on his or her work output Out of the 300 teachers who participated in the study indicated that it was not their choice to be teachers, only $108(36 \%)$ admitted it was their choice to be teachers. This indicates that more than half of the teacher did not want to be teachers and this is likely to negatively manifest in the discharge of their professional duty through poor work habit and consequently result in low academic output. Lockheed et. al. (1991) asserted that lack of motivation and professional commitment produce poor attendance and unprofessional attitudes towards 
pupils, which in turn affect the performance of the pupils academically. Twenty-eight per cent (84) of the teachers agreed that generally teachers have good work habit or attitude towards the teaching profession whiles $72 \%$ (216) disagreed. The findings support Thuranira (2000) who underscores that negative attitude of teachers towards teaching contributed to low performance in primary school. Only $32 \%$ (86) of the teachers agreed the working conditions attached to the teaching profession are satisfactory enough to meet the economic conditions of the country. Majority of them 68\% (204) disagreed. This means most of the teachers perceived unsatisfactory working conditions within the teaching profession. Furthermore, 62\% (186) of the teachers disagreed that there are opportunities for continuous professional development in the teaching service. $38 \%$ (114) agreed .this means most of the teachers are under the impression that job advancement in the teaching service is rare. On availability and adequacy of professional teachers, the results show good supply of adequate professional teachers. Also, $234(78 \%)$ of the teachers agreed to the statement whiles $66(22 \%)$ disagreed. This is a potential for good performance, but unfortunately, this did not reflect in the performance of the pupils as pupil keep attaining poor results.

Table 3: Availability, Adequacy, and Usage of Teaching and Learning Materials (TLMs)

\begin{tabular}{|c|c|c|c|c|c|c|c|}
\hline Statements & $\begin{array}{c}\text { SD } \\
\text { Freq. } \%\end{array}$ & Fre & D. $\%$ & $\begin{array}{l}\text { A } \\
\text { Frec }\end{array}$ & q. $\%$ & $\begin{array}{l}\text { SA } \\
\text { Frec }\end{array}$ & $\%$ \\
\hline $\begin{array}{l}\text { Teaching and learning materials (TLMs) are } \\
\text { available in the school. }\end{array}$ & 4615.3 & 58 & 19.3 & 118 & 39.3 & 78 & 26 \\
\hline $\begin{array}{l}\text { The school has adequate teaching and learning } \\
\text { materials (TLMs) }\end{array}$ & $60 \quad 20$ & 138 & 46 & 56 & 18.7 & 46 & 15.3 \\
\hline $\begin{array}{l}\text { Teachers make adequate use of the (TLMs) } \\
\text { during teaching and learning. }\end{array}$ & 12842.7 & 82 & 27.3 & 60 & 20 & 30 & 10 \\
\hline $\begin{array}{l}\text { Teaching and learning materials aid teaching } \\
\text { and learning. }\end{array}$ & 1.3 & 18 & 6 & 144 & 48 & 134 & 44.7 \\
\hline $\begin{array}{l}\text { Teachers have adequate knowledge and skill in } \\
\text { the usage of (TLMs) }\end{array}$ & 6822.6 & 100 & 33.3 & 86 & 28.7 & 46 & 15.3 \\
\hline
\end{tabular}
Source: Field work data (2017)

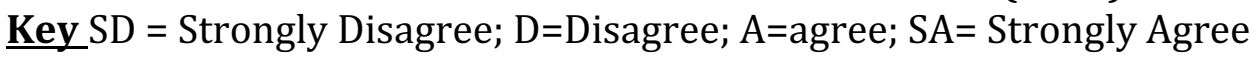

One hundred and four (34.6\%) of the teachers said they had no teaching and learning materials (TLMs) at all and 196 (65.4\%) of the teachers said they had. One hundred and ninety-eight $(66 \%)$ of the teachers indicated inadequate TLMS with $102(34 \%)$ indicated adequate TLMS availability. In addition, $210(70 \%)$ teachers reported that teachers do not make adequate use of the (TLMs) during teaching and learning. Only 90 (30\%) believed the contrary. This could mean that most of the teachers dislike the use of TLMs, even though a vast percentage (92.7\%) of them admitted teaching and learning materials aid teaching and learning. More than half of the teachers (56\%) 168 conceded that teachers lack adequate knowledge and skill in the usage of (TLMs). (44\%) 132 thought otherwise. TLMs enhance teaching and learning because pupils are able to see and often feel what the teacher teaches and this go a long way to stimulate pupils' interest and increase understanding and retention. Since there were inadequate and less use of TLMs by teachers in this study, the situation might had been difficult for the pupils to understand the lessons and this also could led to poor academic performance scores in respective subjects; confirming Estey's (2005) view that lack of teaching and learning materials tends to reduce the effectiveness of teaching in the school system. 
Table 4: Teacher- pupil teaching and learning interactions

\begin{tabular}{|c|c|c|c|c|c|c|c|c|}
\hline Statements & \multicolumn{2}{|c|}{$\begin{array}{l}\text { SD } \\
\text { Freq. \% }\end{array}$} & \multicolumn{2}{|c|}{$\begin{array}{c}\text { D } \\
\text { Freq. } \% \\
\end{array}$} & \multicolumn{2}{|c|}{$\begin{array}{l}\text { A } \\
\text { Freq. \% }\end{array}$} & \multicolumn{2}{|c|}{$\begin{array}{c}\text { SA } \\
\text { Freq. } \%\end{array}$} \\
\hline $\begin{array}{l}\text { I ensure that pupils are able to carry out the } \\
\text { instructional objectives of lessons taught. }\end{array}$ & 44 & 14.7 & $\begin{array}{l}124 \\
41.3\end{array}$ & & 102 & 34 & 30 & 10 \\
\hline $\begin{array}{l}\text { I spend a lot time in remedial teaching to } \\
\text { improve pupils academic performance }\end{array}$ & 84 & 28 & 122 & 40.6 & 56 & 18.7 & 38 & 12.7 \\
\hline I usually motivate pupils to learn hard & 8 & 2.7 & 10 & 3.3 & 82 & 27.3 & 200 & 66.7 \\
\hline $\begin{array}{l}\text { I give pupils enough class exercise and } \\
\text { homework and mark them }\end{array}$ & 42 & 14 & 90 & 30 & 100 & 33.3 & 68 & 22.7 \\
\hline $\begin{array}{l}\text { I make sure pupils effectively participate } \\
\text { during classroom lessons }\end{array}$ & 36 & 12 & 78 & 26 & 78 & 26 & 108 & 36 \\
\hline
\end{tabular}

Source: Field work data (2017).

Key: $\mathrm{SD}=$ Strongly Disagree; $\mathrm{D}=$ Disagree; $A=$ agree; $\mathrm{SA}=$ Strongly Agree

This study also showed that 168 (56\%) of the teachers do not show concern about their pupils' ability to achieve various instructional objectives of lessons taught with 132(44\%) reporting the affirmative. Two hundred and six (68.6\%) teachers seemed not to have provided remedial lessons to support weaker students in their lessons, whiles only 94 (31.4\%) did and this could affect students' achievement scores. Indeed, 282 (94\%) teachers participating in this study reported that they usually motivate pupils to learn hard and $18(6 \%)$ indicated the contrary. One hundred and eighty-six (62\%) of the teachers made sure pupils effectively participated in their classroom lessons, while 114 (38\%) were not sure they encouraged such participation. The findings comes in lights of Farrant's (1996) earlier opinion that it is the teacher's duty and vital responsibility to motivate students in ascertaining their inner strengths and abilities and to discover what truly inspires them. Aggarwal (1994) also believed that best learning takes place when the teacher is successful in arousing the interest of learners.

Table 5: Lesson Note Preparation, Vetting, and Completion of Syllabi

\begin{tabular}{|c|c|c|c|c|c|c|c|}
\hline Statements & $\begin{array}{l}\text { SD } \\
\text { Fre }\end{array}$ & $\%$ & $\begin{array}{l}\text { D } \\
\text { Frec }\end{array}$ & q. $\%$ & $\begin{array}{l}\text { A } \\
\text { Freq. } \%\end{array}$ & $\begin{array}{r}\text { SA } \\
\text { Freq }\end{array}$ & A. $\%$ \\
\hline $\begin{array}{l}\text { Lesson note preparation aid teaching and } \\
\text { learning }\end{array}$ & 36 & 12 & 66 & 22 & 10434.7 & $94:$ & 31.3 \\
\hline $\begin{array}{l}\text { I usually prepare complete lesson note for } \\
\text { effective teaching }\end{array}$ & 62 & 20.7 & 114 & 38 & $80 \quad 26.7$ & 44 & 14.6 \\
\hline $\begin{array}{l}\text { My lesson notes are vetted by the head teacher } \\
\text { on time. }\end{array}$ & 26 & 8.7 & 54 & 18 & 10033.3 & 120 & 40 \\
\hline $\begin{array}{l}\text { I always complete my teaching syllabus and } \\
\text { allow enough time for revision. }\end{array}$ & 84 & 28 & 110 & 36.7 & $\begin{array}{ll}70 & 23.3\end{array}$ & 36 & 12 \\
\hline $\begin{array}{l}\text { Incompletion of teaching syllabus affect } \\
\text { academic performance of pupils negatively. }\end{array}$ & 22 & 7.3 & 38 & 12.6 & 11237.3 & 12 & 82.7 \\
\hline
\end{tabular}

Source: Field work data (2017).

Key: $S D=$ Strongly Disagree; $D=$ Disagree; $A=$ agree; $S A=$ Strongly Agree

Lesson notes serve as a guide for effective teaching and learning. Poor preparation and vetting of lesson notes could have adverse implication on teaching and learning. Hence, 198 (66\%) 
teachers agreed that lesson note preparation aided their teaching and learning with 102 (34\%) thinking differently. One hundred and twenty-four $(41.3 \%)$ teachers reported they wrote complete lesson notes with176 (58.7\%) indicating otherwise. Also, 220 (73.3\%) teachers admitted their lesson notes are vetted by the head teacher on time, $80(26.7 \%)$ of them said their head teachers could not vet their lesson notes on time.

On the issue of syllabus completion, responses revealed that 60 teachers (20\%) completed their syllabi whiles 240 teachers (80\%) said they could not complete the syllabuses. The results showed that fewer teachers completed the syllabuses. The completion of the syllabus for each subject in each class provides the foundation for the next class to be built upon. When the syllabus is not completed, content that should be taught in the next class which is based on the previous class could not be taught (Estey, 2005). In the view of the current study, teachers' inability to complete their syllabi before basic education certificate examinations could have an adverse effect on the performance of pupils since questions might be set from all topics in the syllabi.

Table 6: Frequency of Teacher Lateness and Absenteeism

\begin{tabular}{|c|c|c|c|c|c|c|c|}
\hline Statements & $\begin{array}{c}\text { SD } \\
\text { Fre }\end{array}$ & q. $\%$ & & q. $\%$ & $\begin{array}{l}\text { A } \\
\text { Freq. \% }\end{array}$ & $\begin{array}{l}\text { SA } \\
\text { Fre }\end{array}$ & $\%$ \\
\hline $\begin{array}{l}\text { Teacher lateness to school is a problem in the } \\
\text { school. }\end{array}$ & 44 & 14.7 & 73 & 24.3 & $\begin{array}{ll}89 & 29.7\end{array}$ & 94 & 31.3 \\
\hline $\begin{array}{l}\text { Teacher lateness to school negatively affect } \\
\text { pupils academic performance }\end{array}$ & 4 & 1.3 & 8 & 2.7 & 17859.3 & 110 & 36.7 \\
\hline $\begin{array}{l}\text { Teacher absenteeism is a problem in the } \\
\text { school. }\end{array}$ & 68 & 22.6 & 56 & 18.6 & $98 \quad 32.7$ & 78 & 26 \\
\hline $\begin{array}{l}\text { Teacher absenteeism affects academic } \\
\text { performance of pupils negatively. }\end{array}$ & 0 & 0 & 2 & 0.7 & 24481.3 & 54 & 18 \\
\hline
\end{tabular}

Source: Field work data (2017).

Key: $S D=$ Strongly Disagree; $D=$ Disagree; $A=$ agree; $S A=$ Strongly Agree

Lateness of teachers to school emerged as problem, which could have influence pupils' academic achievement in the BECE. Consequently, 183 (61\%) of the teachers admitted that teacher lateness to school is a problem. 117 (39\%) disagreed to the statement. Lateness to school could mean teachers missing early periods. This makes might contribute to children losing much of what should have been taught, hence inability to complete syllabi resulting in poor academic output. Confirming, this assertion, 288 (96\%) teachers agreed that teacher lateness to school negatively affected pupils academic performance. However, 12 (4\%) disagreed. Etsey (2005) also found teacher lateness to school as among the factors that accounted for low pupils' performance in examination. Since teacher lateness to school was a problem in most of the schools, it could be possible to contribute to the declining academic performance of pupils.

Regarding teacher absenteeism, $176(58.7 \%)$ of the teachers also admitted that it is a problem in their schools, while 124 (41.3\%) did d=not believe so. The results confirms the researchers analysis of 20 teachers' attendance books which revealed that out the 72 working days, $10 \%$ of teachers came to school throughout, $68 \%$ absented school for 1 to 5 days. $2 \%$ and $16 \%$ recorded 6-10 and 11- 15 days absents respectively. Also, 3\% and 1\% recorded absents from 16-20 and above such 20 days respective. This indicated that teachers' absenteeism was a problem is some of the schools and might have accounted for the poor performance of pupils. 
The findings confirms Morakinyo (2003) who observes that the attitude of some teachers to their job is reflected in their poor attendance to lessons, lateness to school, unsavory comments about student's performance that could damage their ego, poor method of teaching and the likes affect pupils' academic performance negatively. Similarly, 298 (99.3\%) of the teachers admitted teacher absenteeism affects academic performance of pupils negatively. only $2(0.7 \%)$ disagreed.

\section{Research question 2}

What strategies can be adopted to improve the academic performances of pupils in the Effutu Municipality? This required teachers to suggest strategies to improve the academic performances.

Table 7: Strategies to Improve Academic Performances

\begin{tabular}{lcc}
$\begin{array}{l}\text { Strategies to improve academic } \\
\text { Performance }\end{array}$ & Freq. & \% \\
\hline Provision of adequate learning /teaching resources & 161 & 53.6 \\
Encourage guidance and counseling in schools & 168 & 56 \\
Encourage teamwork among the pupils and teachers & 109 & 36.3 \\
Teachers and pupils should attend class regularly & 196 & 65.3 \\
Intra-school and interschool academic competition & 110 & 36.7 \\
Head teachers must supervise teaching and learning & 129 & 43 \\
Increase parental involvement in school. & 187 & 62.3 \\
Pupils must avoid negative peer group influence & 156 & 52 \\
Pupils should develop good attitude towards learning & 209 & 69.7 \\
Engagement and partnerships with local community & 140 & 46.7 \\
Culture of speaking English at school & 202 & 67.3 \\
Regular in-service training for teachers & 152 & 50.7 \\
Regular supervision of schools by the district office & 137 & 45.7 \\
Parents provision of basic school needs of wards & 194 & 64.7 \\
\hline
\end{tabular}

Source: Field work data (2017)

Table 4 indicates diverse views of teachers concerning how to improve academic performance. The strategies that were mostly suggested by a majority of the teachers included pupils developing good attitude towards learning, culture of speaking English at school, teachers and pupils should attend class regularly, parents provision of basic school needs of wards, increase parental involvement in school, encourage guidance and counseling in schools, provision of adequate learning /teaching resources, pupils must avoid negative peer group influence and regular in-service training for teachers

\section{CONCLUSION}

The study has revealed a number of teacher-related factors responsible for the declining academic performance of junior high school pupils in Effutu municipality of Ghana. These include lack of teacher job satisfaction resulting in poor work habit, inadequate and less use of teaching and learning materials, syllabi not being completed, lack of opportunities for continuous professional development, poor preparation of lesson note, incidence of lateness and absenteeism and less remedial teaching to improve pupils academic performance. Such significant elements could have repercussions on pupils' achievement scores in the basic education certificate examinations in the municipality. Similarly, prevalence of such negative teacher attitudes could mean that supervision in the municipality' basic schools are weak. 


\section{RECOMMENDATIONS}

In view of the above findings and conclusions, the study makes the following recommendations:

(a) Education authorities should effectively monitor and supervise teachers' instructional activities in the public schools in order to ensure effective and efficient instructional activities and to enhance performance in BECE.

(b) Government should ensure adequate provision of teaching and learning materials and increase remuneration, incentives and allowance for teacher for improved job satisfaction.

(c) There should be regular, effective and efficient organization of in -service training for teacher to sensitize them on various opportunities for continuous professional development in order to improved their knowledge and skills and increase educational outcomes

\section{References}

Adane, L. O. (2010). Factors affecting low academic achievement of pupils in Kemp Methodist Junior High School in Aburi, Eastern Region. Retrieved on $6^{\text {th }}$ March, 2015 from ugspace.ug.edu.gh/.../Linda\%200fosua\%20Adane_Factors\%20Affect

Agyeman, D. K., Baku, J. J. K., \& Gbadamosi, R. (1993). National review of education sector analysis in Ghana, 19871998. Paris: WGESA/UNESCO.

Aremu, A. O. (2000). Academic performance 5 factor inventory. Ibadan: Stirling-Horden Publishers.

Aremu, A.O. \&Oluwole, D.A. (2001).Gender and birth order as predictors of normal pupil's anxiety pattern in examination. Ibadan Journal of Educational Studies, 1, (1), 1-7.

Aremu, O. A \&Sokan, B. O. (2003). A multi-causal evaluation of academic performance of Nigerian learners: Issues and implications for national development. Department of Guidance and Counselling, University of Ibadan, Ibadan.

Avoke, M. 2005. Special education needs in Ghana: Policy, practice and research. Winneba: Special Education Books.

Cohen, L., Manion, L. \& Morrison, K. 2003. Research methods in education. London: Routledge Falmer.

Creswell, J. W. (2009). Research Design: Qualitative, Quantitative, and Mixed Methods Approaches.California: Sage

Darling-Hammond, L. (2000).Reforming Teacher Preparation and Licensing: Debating the Evidence. Teachers College Record, 102, 28-56.

Etsey, K. (2005). Causes of low academic performance of primary school pupils in the Shama Sub-Metro of Shama Ahanta. Retrieved from .www.saga.cornell.edu/saga/educonf/etsey.pdf on May, 2017.

Gay, L.R. (1992). Educational Research competence for analysis and application. Ohio: Millan publish Company.

Ferguson, R. F. (1990). Racial patterns on how school and teacher quality affect achievement and earnings. Dallas: Meadows Foundation.

Hayford, S. K. (2013). Special educational needs and quality education for all. Winneba: Department of Special Education. U.E.W.

Kochhar, S. K. (2004). Methods \& Techniques of Teaching. New Delhi: Sterling Publishers Pvt. Ltd.

Majoribirik, M. (2000). The anatomy of achievements motivation. New York: Academic Press.

Morakinyo, A. (2003). Relative efficacy of systematic desensitization, self-statement monitoring and flooding on subjects test anxiety. Phdthesis. University of Ibadan.

Mukono, N. (2004). Factors that contribute to poor performance of Kiswahili in secondary schools: A case study of Parklands School in Nairobi. Nairobi: Kenyatta University. Unpublished, M.Ed. Thesis.

Oghuvbu E.P (2010). Attendance and academic performance of students in secondary schools: A correlational approach. Studies on Home and Community Science, 4(1), 21-25

Orodho, J.A. (2005). Techniques of writing research proposals and reports in education and social Sciences. Bureau of Education Research Kenyatta University. Nairobi: Reata Printers

Polland, R. J. (2005). Essentials of survey research and analysis. New York: Nova Science Publishers Inc. 
Reynolds, A. R., \& Walberg, H. J. (1992). A process model of mathematics achievement and attitude. Journal of Research in Mathematics, 23, 306-328.

Walberg, H. J. (1981). A psychological theory of educational productivity. In F. H. Farley \& N. Gordon (Eds.), Psychological and Education (pp. 81-110). Chicago: National Society for the Study of Education.

Weirsma W. (1980). Research methods in education: An Introduction). Illinois: F. E. Peacock Publishers Inc.

\section{APPENDIX A \\ QUESTIONNAIRE FOR TEACHERS \\ UNIVERSITY OF EDUCATION, WINNEBA \\ DEPARTMENT OF EDUCATIONAL ADMINISTRATION AND MANAGEMENT}

We are researchers from the University of Education, Winneba. As part of our academic research, we are conducting a research on the declining academic performance of pupils in public junior high schools in the Effutu municipality. We assure you that any information provided shall be used sorely for academic purposes, confidentiality is assured.

\section{(Please tick and specify when appropriate)}

\section{Section A: Background Characteristics}

1. Gender: (a) Male [] (b) Female []

2. Age: (a) Less than 30 years [] (b) 30-39 years [ ] (c) 40-49 years [] (d) 50 \& above []

3. Marital status (a) Single [ ] (b) Married [ ] (c) Divorced [] (d) Separated [ ] (e) Widowed []

4. Educational Qualification (a) Teacher certificate A [ ] (b) Diploma in education [ ]

(c) First Degree (d) Masters [] (e) Postgraduate Diploma [] (f) others

5. Teaching Grade/ Status (a) Professional (b) Non Professional

6. Teaching Experience: (a) 1-5yrs [ ] (b) 6 - 10 yrs. [ ] (c). 11 - 15 yrs. [ ] (d) 16-20yrs [ ]

(e) 21years and above [] 


\section{Section B:}

Respond to each statement by indicating whether you

$\mathrm{SD}=$ Strongly Disagree; $\mathrm{D}=$ Disagree; $\mathrm{A}=$ agree; $\mathrm{SA}=$ Strongly Agree

\begin{tabular}{|c|c|c|c|c|c|}
\hline & Job Satisfaction & SD & $\mathrm{D}$ & A & SA \\
\hline 7 & It is my choice to be a teacher & & & & \\
\hline 8 & I have good work habit or attitude towards the teaching profession. & & & & \\
\hline 9 & $\begin{array}{l}\text { The working conditions attached to the teaching profession are } \\
\text { satisfactory enough to meet the economic conditions of the country. }\end{array}$ & & & & \\
\hline \multirow[t]{2}{*}{10} & $\begin{array}{l}\text { There are opportunities for continuous professional development in the } \\
\text { teaching service }\end{array}$ & & & & \\
\hline & Availability and Adequacy of teaching and learning materials & & & & \\
\hline 11 & Teaching and learning materials are available in the school. & & & & \\
\hline 12 & The school has adequate teaching and learning materials (TLMs) & & & & \\
\hline \multirow[t]{2}{*}{13} & Teachers make use of the(TLMs)during teaching and learning & & & & \\
\hline & Teacher- Pupil Teaching And Learning Interaction & & & & \\
\hline 14 & I make sure pupils understand each lesson & & & & \\
\hline 15 & $\begin{array}{l}\text { I spend a lot time in remedial teaching to improve pupils academic } \\
\text { performance }\end{array}$ & & & & \\
\hline 16 & I usually motivate pupils to learn hard & & & & \\
\hline 17 & I give pupils enough class exercise and home work & & & & \\
\hline
\end{tabular}

\section{Section C:}

Frequency of lateness and absenteeism

18. Is teacher lateness to school is a problem in the school? (a) Yes [ ] (b) No [ ]

19. If yes how often?(a) All the time (b) Sometimes

20. Is teacher's absenteeism from schoola problem in your school? (a) Yes [ ] (b) No [ ]

21. If yes in a term how many days do you absent yourself from school?
(a) 0 days []
(b) 1-5days [ ]
(c) 6-10days []
(d) 11-15 days []
(e) 16-20 days
(f) 20 days and above

\section{Section D:}

\section{Lesson note preparation and vetting and completion of syllabi}

22. Do you prepare lesson note for effective teaching? (a) Yes [ ] (b) No []

23. If yes are your lesson note vetted by your head teacher? (a) Yes [ ] (b) No [ ]

24. Do you complete the teaching syllabus and allow enough time for revision?

(a) Yes [] (b) No []

\section{Thank you.}

